\title{
DASAR FILOSOFIS DAN INKLUSIVITAS GUGATAN SEDERHANA DALAM SISTEM PERADILAN PERDATA
}

\author{
Anita Afriana \\ Fakultas Hukum Universitas Padjadjaran \\ Email : anita.afriana@unpad.ac.id
}

\begin{abstract}
The fast litigation procedure stipulates under the Supreme Court Regulation No. 2 year of 2015. That mechanism only requires small amount of permitted claim, it is 200 million Rupiah in maximum, it also settles claims in a very fast manner, 25 days in maximum. This fast procedural mechanism allocated to settle private dispute is called as "the small claims court", in which, it is already implemented either in states with the civil law system or the common law system. The research methodology used in this article is juridical-normative and juridical kualitative analyze, to aim the SCC phisophy in Indonesia and the effectivity in enacting this mechanism of small claims court as one of the states that enact the civil judicial system. The results shows that the SCC in indonesia is an advancement as a means of access to justice, in short it is a simple and inexpensive procedure. that the fast litigation procedure stipulates under the Supreme Court Regulation No. 2 year of 2015 is effectively enacted in civil judicial system in Indonesia. With society needs nowadays, the effort to increasing good services towards justice seeker, it's inclusive because of the different mechanism of general judicial system under HIR/RBG, it is not just about time but also with a judge investigation, simple evidentiary, and without legal effort.
\end{abstract}

Keywords : civil procedure law, fast procedures, civil judicial system, small claims court.

\section{Pendahuluan}

Sebagai negara hukum, maka demikian pesatnya dinamika dunia bisnis pembangunan bidang hukum di Indonesia yang telah membawa implikasi yang cukup merupakan bagian dari pembangunan mendasar terhadap pranata maupun lembaga nasional, karena hukum sebagai sarana pembaruan masyarakat tidak boleh ketinggalan dari proses perkembangan yang terjadi dalam masyarakat. Demikian pula adanya suatu korelasi antara pembangunan dibidang ekonomi dan pembangunan dibidang hukum. Salah satu perkembangan masyarakat dibidang ekonomi adalah hukum.

Perkembangan yang telah terjadi dalam rangka pembaharuan hukum antara lain adanya peraturan perundang-undangan untuk mendukung kegiatan perdagangan dan bisnis, selain di akomodasi peraturan perundang-undangan juga patut didukung oleh perangkat dan penegakan hukum yang 
tidak menghambat perdagangan dan bisnis, melainkan dapat menyelesaikan sengketa yang terjadi bilamana ada pihak yang merasa dirugikan pihak lain yang dianggap sebagai penyebab kerugian, maka dalam hal ini hukum akan berperan untuk melindungi kepentingan para pihak, sehingga tidak terjadi pihak yang satu dirugikan dan pihak yang lain diuntungkan ${ }^{1}$.

Konflik atau sengketa adalah sesuatu yang menyebabkan perbedaan pendapat antara dua pihak atau lebih yang berselisih perkara dalam pengadilan. Pada prinsipnya, penegakan hukum berkaitan dengan penyelesaian sengketa hanya dilakukan oleh kekuasaan kehakiman (judicial Power) yang secara konstitusional lazim disebut badan yudikatif (Pasal 24 UUD 1945).

Kekuasaan kehakiman di Indonesia menurut UUD RI Tahun 1945 dilakukan oleh Mahkamah Agung dan badan peradilan yang berada dibawahnya, untuk menyelenggarakan peradilan guna menegakkan hukum dan keadilan. Peradilan disebut sebagai the last resort dalam penyelesaian sengketa, meskipun melalui peradilan bukan satu satunya jalan yang dapat ditempuh untuk menyelesaikan sengketa.

Sesuai ketentuan hukum yang berlaku, bahwa satu satunya lembaga resmi yang

${ }^{1} \mathrm{~S}$ Sastrawidjaja, Man. Hukum Kepailitan dan Penundaan Kewajiban Pembayaran Utang (2006). Bandung : Penerbit Alumni. Hlm 71 merupakan pelaksana kekuasaan kehakiman di Indonesia untuk memeriksa dan memutus baik perkara pidana maupun perdata adalah Badan Peradilan Umum, dalam hal ini adalah Pengadilan Negeri yang berdasarkan Pasal 2 ayat (4) Undang-Undang No. 48 Tahun 2009 Tentang Kekuasaan Kehakiman (selanjutnya disebut UUKK) dinyatakan bahwa peradilan dilakukan dengan sederhana, cepat, dan biaya ringan.

Asas peradilan yang cepat, sederhana, dan biaya ringan secara jelas dicantumkan dalam Pasal 2 ayat (4), dan Pasal 4 ayat (2) UUKK, yang kemudian dalam Surat Edaran Mahkamah Agung ( SEMA) Nomor 2 Tahun 2014 Tentang Penyelesaian Perkara di Tingkat Pertama dan Banding Pada 4 (Empat) Lingkungan Peradilan. Melalui SEMA ini dihimbau agar pengadilan tingkat pertama dan banding untuk dapat menyelesaikan sengketa dalam waktu maksimal 5 bulan, namun demikian, dalam pelaksanaannya tidak jarang suatu sengketa diputus setelah melebihi waktu 5 bulan dengan berbagai faktor penyebabnya. Berbagai cara telah diinisiasi agar penyelesaian sengketa tidak berlarut-larut, salah satunya melalui prosedur mediasi di pengadilan seharusnya mampu mempercepat penyelesaian sengketa perdata melalui mediasi (perdamaian) tanpa harus berlanjut pada penyelesaian melalui mekanisme peradilan perdata, namun faktanya proses mediasi seringkali gagal 
mendamaikan para pihak $^{2}$. Pelaksanaan mediasi di pengadilan masih terkesan formalistik, mengakibatkan proses persidangan perkara perdata berlanjut sampai tingkat Mahkamah Agung.

Di sisi lain, penyelesaian sengketa secara non litigasi (secara damai) yang didasarkan pada kesepakatan para pihak, ternyata hasilnya tidak memiliki kekuataan mengikat secara formal bagi para pihak, meskipun undang-undang mengharuskan agar kesepakatan para pihak tersebut dituangkan dalam bentuk akta tertulis dan didaftarkan ke Pengadilan Negeri. Menurut sistem hukum acara yang berlaku, bahwa terhadap akta hasil kesepakatan yang telah dicapai tersebut tidak dapat langsung dimohonkan ke pengadilan untuk dijadikan putusan perdamaian hakim (acta van dading), tetapi para pihak harus tetap mengajuan gugatan ke pengadilan dengan melampirkan akta kesepakatan dimaksud, baru kemudian diputus dalam persidangan berdasarkan akta perdamaian yang telah dicapai para pihak di luar pengadilan tersebut, dengan putusan perdamaian hakim (acta van dading).

Cara penyelesaian sengketa non litigasi lainnya adalah melalui arbitrase yang bersifat yudisial (melalui proses peradilan)

\footnotetext{
${ }^{2}$ Irawan, Chandra, "Problematika Penerapan Peraturan Mahkamah Agung Republik Indonesia Nomor 1 tahun 2008 Dalam Penyelesaian Sengketa Perdata di Indonesia", Jurnal Hukum Acara Perdata ADHAPER, Vol 1. Hlm 62.
}

meskipun arbitrase bukanlah badan peradilan melainkan lembaga penyelesaian sengketa. Pada praktiknya, melalui lembaga arbitrase juga seringkali tidak mencapai penyelesaian sengketa yang efektif dan efisien, karena sekalipun telah ada pengaturan yang jelas tentang kompetensi mengadili yang absolut antara pengadilan dengan arbitrase, para pihak yang bersengketa seringkali masih juga mengajukan sengketanya ke pengadilan dan pengadilan memeriksa serta memutus perkara tersebut, karenanya penyelesaian sengketa menjadi tidak efektif dan efisien $\operatorname{lagi}^{3}$

Proses beracara yang hingga saat ini berlaku yaitu HIR dan atau RBg tidak membedakan prosedur beracara berdasarkan pada besar kecilnya nilai gugatan, dengan kata lain sebelum tahun 2015 dalam sistem peradilan perdata yang didasarkan pada ketentuan HIR dan atau RBg penyelesaian perkara dilakukan tanpa membedakan lebih lanjut besar kecilnya nilai gugatan serta sederhana tidaknya pembuktian.

Prosedur penyelesaian sengketa di pengadilan melalui tahapan beracara yang harus dilalui, ditenggarai sebagai salah satu penyebab lamanya penyelesaian sengketa

${ }^{3}$ Fakhriah. E.L. "Mekanisme Small Claims Court Dalam Mewujudkan Tercapainya Peradilan Sederhana, Cepat, dan Biaya Ringan". Mimbar Hukum Journal, Vol 25 No. 2, 2013. Hlm 259. 
melalui pengadilan, di samping faktor kehadiran dan domisili dari para pihak. Keadaan ini pada akhirnya menuju kearah penyelesaian sengketa yang tidak berdasarkan pada asas peradilan yang cepat, sederhana, dan biaya ringan, melainkan sebaliknya akan menjadikan suatu perkara menjadi berlarut-larut, memakan waktu dan biaya yang besar. Bagi para pihak yang mengajukan gugatan dengan nilai kecil, lamanya proses beracara hingga diperoleh putusan tidak sebanding dengan nilai gugatan yang dituntut. Pada akhirnya, lembaga peradilan yang secara konkret mengemban tugas untuk menegakkan hukum dan keadilan ketika menerima, memeriksa, mengadili, serta menyelesaikan setiap sengketa yang diajukan, dianggap sebagai tempat menyelesaikan sengketa yang tidak efektif dan efisien ${ }^{4}$, namun demikian penyelesaian sengketa melalui pengadilan yang bersifat formal akan menghasilkan putusan yang memberikan kepastian hukum. Hal ini berbeda dengan penyelesaian sengketa yang dilakukan dengan mekanisme di luar pengadilan yang memang relatif lebih cepat, tetapi dalam keadaan tertentu masih memerlukan penetapan pengadilan untuk dapat dieksekusi.

${ }^{4}$ Suparman. E. (2012) Arbitrase \& Dilema Penegakan Keadilan, Jakarta : PT. Fikahati Aneska. Hlm 2
Seiring dengan semakin berkembangnya hubungan hukum dibidang ekonomi dan keperdataan lainnya di masyarakat membutuhkan prosedur penyelesaian sengketa yang lebih sederhana, cepat, sehingga biaya yang dikeluarkan juga ringan, terutama di dalam hubungan hukum yang bersifat sederhana. Oleh karenanya, pada tanggal 7 Agustus 2015 Mahkamah Agung mengeluarkan PerMa No. 2 Tahun 2015 Tentang Tata Cara Penyelesaian Gugatan Sederhana.

Pasal 1 PerMa No. 2 Tahun 2015, menyebutkan bahwa yang dimaksud dengan penyelesaian gugatan sederhana adalah tata cara pemeriksaan di persidangan terhadap gugatan perdata dengan nilai gugatan materil paling banyak Rp 200.000.000,00 (dua ratus juta rupiah) yang diselesaikan dengan tata cara dan pembuktiannya sederhana.

Pada negara-negara dengan latar belakang common law, berkembang metode dan telah lama menggunakan penyelesaian sengketa yang disebut Small Claims Court ( selanjutnya disingkat SCC). Model penyelesaian sengketa SCC merupakan sistem penyelesaian sengketa yang sederhana, dengan hakim tunggal, tanpa juri, dan pembuktian yang sederhana. Saat ini, negara-negara tidak menerapkan sistem hukum yang berlaku sebelumnya secara murni, selain di Singapore, Amerika Serikat, Australia, dan negara common law 
lainnya, SCC diterapkan pula pada beberapa negara dengan sistem civil law seperti Jepang dan Belanda. Penerapan SCC di negara-negara tersebut, dinilai cukup efektif untuk menyelesaikan sengketa dengan nilai kerugian kecil secara cepat dan efisien. Acara cepat yang digunakan untuk menyelesaikan gugatan sederhana sebagaimana yang diatur dalam PerMA No. 2 Tahun 2015 memiliki konsep yang sama dengan SCC. Dengan diberlakukannya acara cepat, maka secara filosofi akan memberikan akses terhadap keadilan (access to justice).

Kemudahan akses masyarakat untuk mendapatkan keadilan sesungguhnya dapat terwujud antara lain dengan adanya sarana dan prasarana yang memadai, mulai gedung pengadilan yang mudah dijangkau, penataan gedung yang "ramah", jumlah aparat yang cukup dan profesional, serta pilihan-pilihan metode penyelesaian masalah dan bahkan ketersediaan wadah untuk keberatan jika masyarakat tidak puas dengan kinerja lembaga yang ada. Oleh karenanya diperkenalkan dan diaturnya SCC sebagai salah satu metode penyelesaian sengketa bagi gugatan sederhana merupakan langkah konkret dalam rangka terwujudnya asas cepat, sederhana, dan biaya ringan, serta merupakan strategi penting dalam penguatan akses masyarakat terhadap keadilan di Indonesia, setidaknya karena Indonesia telah menyatakan diri sebagai negara hukum (Pasal 1 ayat (3) UUD RI Tahun 1945).

Artikel ini ditulis berdasarkan pada hasil penelitian yang telah rampung, dengan pokok permasalahan yang diteliti berkaitan dengan : Bagaimana Dasar Filosofis dari gugatan sederhana ( Small Claims Court) di Indonesia? Dan Bagaimana penerapan serta inklusivitas gugatan sederhana dalam sistem Peradilan Perdata, khususnya di Pengadilan Negeri Bandung?

Berdasarkan pada permasalahan yang diteliti, maka adapun yang menjadi tujuan dalam penulisan artikel ini adalah Mengulas dasar Filosofis dari Penerapan gugatan sederhana (Small Claims Court ) di Indonesia dan Mengetahui penerapan serta inklusivitas gugatan sederhana dalam sistem Peradilan Perdata, khususnya di Pengadilan Negeri Bandung

\section{Metode Penelitian}

Metode penelitian yang digunakan dalam penelitian ini adalah yuridis normatif. Sebagai penelitian hukum normatif atau kepustakaan menitikberatkan pada data kepustakaan, atau data sekunder melalui asas-asas hukum,sistematika hukum, sinkronisasi, perbandingan hukum, dan sejarah hukum. Penelitian dengan perspektif hukum/yuridis ini ini terfokus pada normatif berkaitan dengan kaidah/norma Hukum Acara Perdata dan perbandingan hukum melalui asas-asas hukum adalah penelitian 
terhadap norma-norma hukum yang merupakan patokan-patokan untuk bertingkah laku yang pantas. Sesuai dengan metode penelitian yang digunakan, maka kajian dilakukan terhadap norma-norma dan asas-asas yang terdapat dalam data sekunder, yang tersebar dalam bahan hukum primer, sekunder, maupun tersier. Hal ini meliputi kajian terhadap perundangundangan tentang acara perdata, penyelesaian sengketa, buku - buku acara perdata dan penyelesaian sengketa perdata, serta sistem hukum dan perkembangannya, artikel dalam jurnal yang terkait dengan objek penelitian dan merumuskan ius constituendum sebagai norma ideal yang harus diwujudkan. Kajian perbandingan hukum dimaksudkan untuk mengetahui pengatur (konsepsi) yang bersifat universal dalam praktik di negara lain, antara lain di Singapura.

Pengumpulan data dilakukan dengan cara melakukan studi dokumen dan wawancara melalui korespodensi yang antara lain dilakukan dengan State Court of Singapore dan wawancara hakim. Studi dokumen dilakukan terhadap data sekunder untuk mendapatkan landasan teoretis berupa bahan-bahan hukum yang terdiri dari badan hukum primer, bahan hukum sekunder, dan tersier yang dianalisis secara kualitatif, dan disajikan secara deskriptif analitis. Untuk menyusun simpulan, penulis antara lain akan menggunakan perbandingan hukum dengan kajian futuristik

\section{Analisis dan Pembahasan}

Hukum positif sebagai ketentuan yang bersifat lex generalis digunakan dalam menyelesaikan sengketa perdata di pengadilan adalah HIR yang berlaku untuk Pulau Jawa dan Madura, dan RBg untuk diluar Pulau Jawa dan Madura. Ketentuan beracara yang ada dalam $\mathrm{HIR} / \mathrm{RBg}$ sarat dengan aturan "main" yang bersifat formal dan memaksa. Sebagai peraturan warisan penjajah, banyak hal yang diatur dalam HIR/RBg sudah tidak sesuai lagi dengan kebutuhan dan perkembangan masyarakat.

Berdasarkan konsep agar perundangundangan menampung aspirasi masyarakat pencari keadilan, harus pula dipahami bahwa tujuan hukum itu adalah sebagai sesuatu yang diadakan untuk memenuhi kebutuhan yang paling utama dari masyarakat, berupa keselamatan umum (the end of low it seems to be concieved as existing to satisfy a paramount social want of general security).

Menurut pandangan Mochtar Kusumatmadja, tujuan pokok dan pertama dari segala hukum adalah ketertiban (order), yang merupakan syarat fundamental bagi adanya suatu masyarakat yang teratur. Untuk tercapai ketertiban, diperlukan kepastian dalam pergaulan antar manusia 
dalam masyarakat. Tujuan kedua setelah ketertiban adalah keadilan, yang isi keadilan ini berbeda menurut masyarakat dan zamannya.

Adil adalah salah satu sifat yang harus dimiliki oleh manusia dalam rangka menegakkan kebenaran kepada siapa pun tanpa terkecuali walaupun akan merugikan dirinya sendiri. Secara terminologis, adil berarti "mempersamakan sesuatu dengan yang lain, baik dari segi nilai maupun dari segi ukuran, sehingga sesuatu itu menjadi tidak berat sebelah satu sama lain".

Keadilan merupakan sebuah nilai esensial ( essential value) dari hukum, bahkan sering keduanya diidentikkan sebagai sebuah nilai yang tunggal dan menyatu. Hukum memiliki banyak tujuan karena hukum tidak hanya berfungsi sebagai sebuah alat untuk meneggakkan keadilan as a tool), namun juga berfungsi sebagai “ cermin". John Rawls, dalam Theory of Justice mengkonsepkan keadilan sebagai fairness yang mengandung asas asas "bahwa orang-orang yang merdeka dan rasional yang berkehendak untuk mengembangkan kepentingankepentingannya hendaknya memperoleh suatu kedudukan yang sama pada saat akan memulainya dan itu merupakan syarat yang fundamental bagi mereka untuk memasuki perhimpunan yang mereka kehendaki",
Rawls merumuskan dua prinsip keadilan distributif, yaitu the greatest equal principle, bahwa setiap orang harus memiliki hak yang sama atas kebebasan dasar yang paling luas, seluas kebebasan yang sama bagi semua orang. Dengan kata lain, hanya dengan adanya jaminan kebebasan yang sama bagi semua orang maka keasilan akan terwujud. Sedangkan prinsip the greatest equal principle, merupakan prinsip kesamaan hak yang memberikan kesetaraan hak dan berbanding terbalik dengan beban kewajiban yang dimiliki semua orang.

Tugas badan peradilan adalah menyelenggarakan peradilan guna menegakkan hukum dan keadilan. Menyadari hal ini, orientasi perbaikan yang dilakukan MA mempertimbangkan kepentingan pencari keadilan dalam memperoleh keadilan. Adalah keharusan bagi setiap badan peradilan untuk meningkatkan pelayanan publik dan memberikan jaminan proses peradilan yang adil.

Indonesia adalah negara hukum, penegakan prinsip keadilan adalah salah satu ciri dari negara hukum. Keadilan adalah hak dasar manusia yang sejalan dengan prinsip persamaan di muka hukum, Keadilan, bagi para pencari keadilan pada dasarnya merupakan suatu nilai yang

\footnotetext{
${ }^{5}$ Rawls. J. (1997). A Theory of Justice, Cambridge, Massachuset: Harvard University Press. Hlm 61.
} 
subyektif, karena adil menurut satu pihak belum tentu adil bagi pihak lain. Penyelenggaraan peradilan atau penegakan hukum harus dipahami sebagai sarana untuk menjamin adanya suatu proses yang adil, dalam rangka menghasilkan putusan yang mempertimbangkan kepentingan (keadilan menurut) kedua belah pihak. Senada dengan pernyataan di atas, Jeremy Bentham berpendapat bahwa pembentuk undangundang hendaknya dapat melahirkan undang-undang yang dapat mencerminkan keadilan bagi semua individu. SCC yang digunakan untuk menyelesaikan gugatan sederhana, di negara lain baik yang bersistem hukum civil law maupun common law bertujuan meningkatkan akses kepada pengadilan untuk memperoleh access to justice.

Sejalan dengan hal di atas, melalui cetak biru (Blue Print) Pembaharuan Peradilan Mahkamah Agung 2010 -2035, terdapat beberapa hal yang menjadi fokus perhatian untuk perbaikan lembaga peradilan yang dikarenakan:

1. Lamanya proses berperkara. Hal ini berkaitan dengan pengeluaran biaya yang diperlukan di pengadilan menjadi sulit untuk diprediksi;

2. Kurangnya pemahaman pencari keadilan dan pengguna pengadilan mengenai prosedur, dokumen dan persyaratan yang diperlukan;
3. Minimnya kepercayaan masyarakat terhadap lembaga peradilan;

Negara-negara dengan sistem hukum baik common law maupun civil law, telah lebih dulu menerapkan Small Claims Court (SCC) sebagai sebuah lembaga penyelesaian sengketa perdata (civil claim) yang memeriksa dan memutus sengketa bernilai kecil dengan cara sederhana, tidak formal, cepat, dan biaya murah. Prosedur yang digunakan dalam SCC untuk memeriksa gugatan dengan nilai kecil secara cepat dan sederhana disebut sebagai Small Claims Procedure (SCP). Dengan menerapkan SCP, maka perkara menjadi lebih cepat selesai dibandingkan dengan sengketa lain yang tidak masuk kategori SCP.

Praktik dibeberapa negara seperti Australia, Singapura, Amerika, dan Jepang, SCC digunakan untuk memeriksa dan memutus perkara dengan nilai gugatan kecil misalnya tidak lebih dari 100 juta. Di Singapura khususnya untuk klaim lebih dari 200 juta pun dapat diselesaikan secara cepat asalkan kedua belah pihak menyetujui secara tertulis, sedangkan di Eropa sejak tahun 2009, semua negara yang tergabung dalam Uni Eropa kecuali Denmark, pengadilannya telah mengenal prosedur klaim kecil/SCP dengan nilai gugatan tidak 
melebihi $2000 \quad$ Euro $^{6}$ Dengan diberlakukannya SCC, maka secara filosofi sebagai sarana mewujudkan akses terhadap keadilan (selanjutnya dalam disertasi ini disebut: access to justice) bagi para pihak, dengan putusan yang cepat sebanding dengan gugatan yang bernilai kecil.

Menurut Laporan Tahunan Mahkamah Agung RI tahun 2013, bahwa kebijakan access to justice antara lain meliputi ${ }^{7}$ :

1. Perubahan kebijakan layanan hukum bagi masyarakat tidak mampu di pengadilan: pembebasan biaya perkara, Pos Bantuan Hukum, sidang diluar gedung pengadilan;

2. Mediasi;

3. Pelayanan terpadu hak identitas hukum;

4. Makanisme penyelesaian gugatan sederhana ( Small Claims);

Berdasarkan Laporan Mahkamah Agung tersebut dapat disimpulkan bahwa access to justice tidak saja berkaitan dengan pelayanan terhadap masyarakat tidak mampu yang membutuhkan layanan hukum tetapi juga berkaitan dengan mekanisme penyelesaian perkara yang efektif dan

\footnotetext{
${ }^{6}$ Singapore Court System http://www.lawsoceety.org diunduh pada hari Kamis, 05 Februari 2015 Pukul 10.15 WIB).

${ }^{7}$ Laporan Tahunan Mahkamah Agung Republik Indonesia 2013 terbit Februari 2014,http://www.mahkamahagung.go.id/Jakarta: Mahkamah Agung, diunuh pada hari Minggu, 1 November 2015 Pukul 15.00 WIB).
}

efisien seperti adanya mediasi dan penyelesaian gugatan secara sederhana.

Bahwa keadilan merupakan cita-cita dan tujuan hukum yang diwujudkan melalui hukum. Akses terhadap keadilan merupakan hak dasar (inti) dan konsep sentral dalam bidang yang lebih luas dari sekedar keadilan. Isi dan ruang lingkupnya tak terbatas dan mencakup hanya pengakuan hak, dan pengetahuan hukum, tetapi juga meluas kepada akses yang sama ke semua mekanisme pengadilan yang adil, tidak memihak dan kecepatan dalam penyelesaian sengketa; ketersediaan informasi yang berkaitan dengan hak-hak dalam sistem peradilan peradilan serta keputusan pengadilan. Menjadi perdebatan dikalangan ahli hukum dunia bahwa perlunya perubahan prosedur (procedual rules) yang berkaitan dengan faktor biaya dan efisiensi penyelesaian sengketa di pengadilan untuk mencapai akses terhadap keadilan ${ }^{8}$.

Fokus akses terhadap keadilan mengalami perkembangan, pada awalnya akses terhadap keadilan hanya menekankan upaya penyediaan bantuan hukum bagi masyarakat miskin, kemudian berkembang menjadi penyatuan kepentingan dari para pihak yang berperan dalam pemberian akses terhadap keadilan bagi masyarakat miskin, dengan konsep yang berfokus pada tujuan dasar dari keberadaan suatu sistem hukum.

${ }^{8}$ Craston. R. (2004) The Rational Study of Law:Social Research and Access To Justice. Oxford: Oxford University Press. HIm 34. 
Perkembangan berikutnya adalah pada langkah-langkah mendukung reformasi yang tengah berlangsung untuk mencapai tujuan yang lebih besar lagi yaitu pembenahan sistem hukum untuk mencapai bentuk negara hukum yang ideal' 9 .

Selaras dengan kebijakan akses terhadap keadilan tersebut, dibutuhkan strategi reformasi hukum dan peradilan secara lebih komprehensif dan sistematis, yang ditujukan untuk memudahkan masyarakat untuk mendapat keadilan salah satunya melalui pembaharuan sistem peradilan perdata yaitu diperkenalkannya acara cepat.

Keberadaan gugatan sederhana/SCC dimaksudkan untuk meningkatkan akses ke pengadilan dengan menyediakan layanan yang bersifat cepat, murah, dan adil. Ditenggarai tingginya biaya proses hukum dapat menjadi penghalang untuk memperoleh keadilan, terutama dalam gugatan sederhana. Gugatan sederhana sebagai mekanisme penyelesaian sengketa perdata di pengadilan bagi gugatan dengan nilai kecil sangat efisien dan efektif, maka melalui mekanisme gugatan sederhaa merupakan salah satu penunjang tercapainya asas peradilan yang sederhana, cepat, dan biaya ringan sebagaimana yang diamatkan

\footnotetext{
${ }^{9}$ Afriana. A. "Towards Access To Justice: Quick Procedures In Civil Dispute Settlement In Indonesia", Makalah pada International Conference Access To Justice, Malang: 21 November 2015, diselenggarakan oleh Fakultas Hukum Universitas Brawijaya. Hlm 6.
}

undang-undang dan diharapkan oleh masyarakat pencari keadilan.

Berdasarkan penelusuran dokumen yang penulis lakukan, sejak PerMa No. 2 Tahun 2015 diberlakukan telah banyak gugatan sederhana yang telah diputus, antara lain di Pengadilan Negeri Jakarta Pusat yang menjadi tempat penelitian baik terhadap perkara wanprestasi maupun perbuatan melawan hukum. SCC yang digunakan dalam penyelesaian gugatan sederhana merupakan salah satu bentuk pembaharuan hukum yang efektif karena dibutuhkan sesuai dengan kebutuhan masyarakat yang berkembang.

Berdasarkan uraian di atas, maka dapat diambil kesimpulan bahwa landasan filosofis dari diterapkannya SCC di Indonesia yaitu didasarkan pada teori keadilan dan teori hukum pembangunan. Berkaitan dengan proses penegakan hukum, menurut Bagir Manan, dalam masyarakat yang menjunjung tinggi hukum, persoalan tata cara mewujudkan tujuan sama penting dengan tujuan itu sendiri ${ }^{10}$. Tujuan mewujudkan keadilan hanya dapat dicapai dengan cara-cara yang adil pula. Cara-cara yang dimaksud meliputi unsur-unsur kepastian kelembagaan, kepastian mekanisme, dan berbagai keluaran yang

\footnotetext{
${ }^{10}$ Manan. Bagir. (2009) Penegakan Hukum yang Berkeadilan, dalam Menegakkan Hukum Suatu Pencarian, Jakarta: Asosiasi Advokat Indonesia. Hlm 58.
} 
dapat diperkirakan (prediktif). Penerapan hukum acara harus secara fleksibel, tidak kaku dan formalistik, demi kepentingan pencari keadilan yang selalu menghendaki penyelesaian perkara secara sederhana, cepat, murah, tuntas, dan final.

Persoalan keadilan memang tidak mudah diwujudkan karena banyak faktor penyebabnya. Makna keadilan sendiri dapat berbeda, antara lain keadilan substantif menyangkut isi keadilan itu sendiri di mana secara teoritik banyak pandangan mengenai hal tersebut. Ada yang melihat dari tingkat pencapaian kepuasan, ada yang memandang dari sudut manfaat, atau ada pula yang memandang keadilan semata-mata diukur dari pelaksanaan hukum itu sendiri. Oleh karena itu, urusan keadilan tidak hanya ditentukan oleh hukum materiil (substantif) tetapi juga oleh hukum acara (hukum formil). Dengan kata lain, kedua aspek hukum tersebut harus terpenuhi atau tersedia sebagai upaya untuk mewujudkan keadilan substantif. Oleh karenanya keadilan yang peroleh para pihak dengan waktu yang cepat dalam menyelesaikan perkara sebanding dengan nilai gugatan yang kecil juga adanya reformasi dalam hal prosedur beracara di pengadilan sesuai dengan kebutuhan masyarakat dewasa ini.

Secara konsep, gugatan sederhana (SCC) merupakan suatu lembaga hukum yang dimaksudkan untuk memberikan solusi yang cepat dan ekonomis untuk menyelesaikan sengketa yang tidak membutuhkan biaya yang mahal. Pada umumnya, SCC juga diartikan sebagai "Pengadilan Rakyat" atau pengadilan konsiliasi bagi masyarakat yang sangat membutuhkan suatu lembaga penyelesaian sengketa yang tidak memerlukan biaya tinggi dan dilakukan dengan proses yang cepat $^{11}$

Sementara itu, adanya prosedur gugatan sederhana di Indonesia ditujukan untuk menyongsong era perdagangan bebas ASEAN mulai 2015 yang diperkirakan banyak terjadi konflik perkara-perkara niaga/bisnis dalam skala kecil yang berujung ke pengadilan, sehingga melalui gugatan sederhana yang diselesaikan dengan SCC diharapkan dapat mempercepat proses penyelesaian perkara sesuai asas peradilan sederhana, cepat, biaya ringan, mengingat selama ini masyarakat pencari keadilan masih mengeluhkan lamanya proses berperkara di pengadilan. Karena itu, diperlukan percepatan proses persidangan dengan sistem peradilan SCC yang sangat penting bagi dunia perdagangan dan investor yang klaim gugatannya kecil agar proses pemeriksaan diselesaikan secara cepat.

Ketua Pengadilan, Hatta Ali mengungkapkan di era perdagangan bebas, Indonesia menjadi sorotan masyarakat

\footnotetext{
${ }^{11}$ Texas Young Lawyers Association and the State
} Bar of Texas. (2009) . Hlm 1. 
ekonomi dunia karena tidak memiliki SCC. Karena itu, MA menerbitkan PERMA No. 2 Tahun 2015 dalam upaya mewujudkan negara demokrasi modern dan meningkatkan pelayanan terbaik bagi masyarakat pencari keadilan ${ }^{12}$

Salah satu perwujudan kewenangan MA sebagai pemegang kekuasaan regelende functie tersebut adalah dengan membentuk Peraturan MA Tentang Tata Cara Penyelesaian Gugatan Perkara Sederhana. Terdiri dari 9 Bab dan 33 Pasal, uraian di bawah ini merupakan beberapa hal yang diatur dalam PerMA No. 2 tahun 2015 yang merupakan prosedur beracara sendiri berbeda dengan pengaturan dalam HIR/RBg: Peraturan Mahkamah Agung No.

2 Tahun 2015 Tentang tata Cara Penyelesaian Gugatan Sederhana ditetapkan di Jakarta pada tanggal 7 Agustus 2015. Tata cara penyelesaian gugatan sederhana dengan nilai gugat kecil menggunakan konsep SCC, diselesaikan oleh hakim tunggal paling lama 25 hari sejak hari sidang pertama.

Peran hakim dalam gugatan sederhana adalah mengutamanakan perdamaian dengan memperhatikan batas waktu yang telah ditetapkan (25 hari). Upaya perdamaian yang dimaksud mengecualikan ketentuan yang diatur dalam Peraturan Mahkamah Agung Tentang Prosedur

\footnotetext{
${ }^{12}$ http://www.pembaruanperadilan.net/v2/2014/04/ma -upayakan-inisiasi, diunduh pada hari Minggu tanggal 27 Desember 2015 Pukul 20.05 WIB
}

Mediasi. Jika tercapai perdamaian, hakim akan membuat putusan akta perdamaian yang mengikat para pihak, yang terhadap putusan tersebut tidak dapat diajukan upaya hukum. Adapun peran hakim lainnya dalam penyelesaian perkara sederhana meliputi:

a. Memberikan penjelasan mengenai acara gugatan sederhana secara berimbang kepada para pihak;

b. Mengupayakan penyelesaian perkara secara damai termasuk menyarankan kepada para pihak untuk melakukan perdamaian di luar persidangan;

c. Menuntut para pihak dalam pembuktian, dan

d. Menjelaskan upaya hukum yang dapat ditempuh para pihak.

Sebelum lahirnya PerMA No. 2 Tahun 2015, perkara dengan nilai gugatan kecil dan sederhana harus melalui tahapan beracara di pengadilan secara konvensional sebagaimana yang diatur dalam $\mathrm{HIR} / \mathrm{RBg}$. Selanjutnya jika tidak puas dengan putusan PN, salah satu pihak dapat melanjutkan pada upaya hukum banding dan kasasi, hal ini tidak sejalan dengan asas sederhana, cepat, dan biaya ringan dalam penyelenggaraan peradilan yang sesungguhnya didesain untuk membuka akses yang luas bagi masyarakat dalam memperoleh keadilan.

Kehadiran PerMa No. 2 Tahun 2015 adalah sebagai sebuah langkah besar 
Mahkamah Agung dalam rangka pembaharuan sistem peradilan perdata karena acara cepat ini tidak pernah dikenal dan diatur sebelumnya dalam HIR dan RBg. Bersifat inklusivitas dalam sistem peradilan perdata karena selain berbeda antara SCC dengan proses beracara perdata pada umumnya, keberadaan SCC sebagai wujud nyata untuk mewujudkan peradilan yang diselenggarakan secara cepat, murah, dan sederhana.

Berdasarkan hasil penelitian lapangan yang dilakukan di Pengadilan Negeri Bandung, gugatan sederhana ini cukup efektif digunakan. Dengan jangka waktu penyelesaian yang relatif singkat yaitu 25 hari, diajukan baik untuk perbuatan melawan hukum maupun sengketa wanprestasi. Di Pengadilan Negeri Bandung, selama kurun waktu 2017 terdapat 10 perkara yang diajukan dengan mekanisme gugatan sederhana, dan sangat efektif digunakan untuk menyelesaikan sengketa kredit dengan kreditor bank yang diajukan dengan jaminan kuasa menjual.

\section{Kesimpulan}

Secara filosofis, keberadaan mekanisme gugatan sederhana didasarkan tujuan tercapainya keadilan bagi pihak yang mengajukan perkara. Oleh karenanya keadilan yang peroleh para pihak dengan waktu yang cepat dalam menyelesaikan perkara sebanding dengan nilai gugatan yang kecil juga adanya reformasi dalam hal prosedur beracara di pengadilan sesuai dengan kebutuhan masyarakat dewasa ini. Tujuan mewujudkan keadilan hanya dapat dicapai dengan cara-cara yang adil pula, cara-cara yang dimaksud meliputi unsurunsur kepastian kelembagaan, kepastian mekanisme, dan berbagai keluaran yang dapat diperkirakan (prediktif). Penerapan hukum acara harus secara fleksibel, tidak kaku dan formalistik, demi kepentingan pencari keadilan yang selalu menghendaki penyelesaian perkara secara sederhana, cepat, murah, tuntas, dan final yang sesuai dengan kebutuhan masyarakat dewasa ini di Indonesia.

Kehadiran PerMa No. 2 Tahun 2015 adalah sebagai sebuah langkah besar Mahkamah Agung dalam rangka pembaharuan sistem peradilan perdata karena gugatan sederhana ini tidak pernah dikenal dan diatur sebelumnya dalam HIR dan RBg. Bersifat inklusivitas dalam sistem peradilan perdata karena terdapatnya perbedaan pemeriksaan perkara antara gugatan sederhana dengan proses beracara perdata pada umumnya, dan berdasarkan hasil penelitian lapangan diketahui bahwa keberadaan gugatan sederhana di Pengadilan Negeri Bandung sebagai wujud nyata untuk mewujudkan peradilan yang diselenggarakan secara cepat, murah, dan sederhana. 


\section{DAFTAR PUSTAKA}

\section{Buku-Buku:}

Bagir Manan. (2009). Penegakan Hukum yang Berkeadilan, dalam Menegakkan Hukum Suatu Pencarian, Jakarta: Asosiasi Advokat Indonesia.

Eman Suparman. (2012). Arbitrase \& Dilema Penegakan Keadilan, Jakarta: PT. Fikahati Aneska.

John Rawls. (1998) A Theory of Justice, Cambridge, Massachuset: Harvard University Press.

Man S Sastrawidjaja. (2006) Hukum Kepailitan dan Penundaan Kewajiban Pembayaran Utang, Bandung: Penerbit Alumni.

Ross Craston. (2004) The Rational Study of Law:Social Research and Access To Justice, Oxford: Oxford University Press.

Texas Young Lawyers Association and the State Bar of Texas. (2009). How to Sue in Small Claims Court, 5th Edition, Texas.

\section{Peraturan Perundang-undangan}

Het Herzienne Indonesisch Reglement (HIR atau Reglemen Indonesia yang diperbaharui: Stb. 1848 no.16, Stb. 1941 no. 44) untuk wilayah Jawa dan Madura.

Rechtsreglement Buitengewesten (RBg)

Undang-Undang No. 8 Tahun 1999 Tentang Perlindungan Konsumen

Undang-Undang No. 30 Tahun 1999 Tentang Arbitrase dan Alternatif Penyelesaian Sengketa.

Undang-Undang No. 48 Tahun 2009 Tentang Kekuasaan Kehakiman.
PerMA No. 1 Tahun 2016 Tentang Prosedur Mediasi di Pengadilan

SEMA No. 2 Tahun 2014 Tentang Penyelesaian Perkara di Pengadilan Negeri dan Pengadilan Tinggi.

\section{Jurnal:}

Candra Irawan, Problematika Penerapan Peraturan Mahkamah Agung Republik Indonesia Nomor 1 tahun 2008 Dalam Penyelesaian Sengketa Perdata di Indonesia", Jurnal Hukum Acara Perdata ADHAPER, 2015, Vol 1 No. 2.

Efa Laela Fakhriah, Mekanisme Small Claims Court Dalam Mewujudkan Tercapainya Peradilan Sederhana, Cepat, dan Biaya Ringan, Mimbar Hukum Journal, 2013, Vol 25 No. 2.

\section{Makalah}

Anita Afriana, "Towards Access To Justice: Quick Procedures In Civil Dispute Settlement In Indonesia”, Disampaikan Dalam International Conference Access To Justice, diselenggarakan Fakultas Hukum Universitas Brawijaya, Malang Tanggal 21 November 2015.

\section{Sumber Internet}

Singapore $\quad$ Court $\quad$ System http://www.lawsoceety.org http//www. europa.eu/legislation_summaries https://www.statecourts.gov.sg/Smallclaims/ Pages/GeneralInformation.aspx. (http://www.pembaruanperadilan.net/v2/201 4/04/ma-upayakan-inisiasi (http://www.eodb.ekon.go.id 